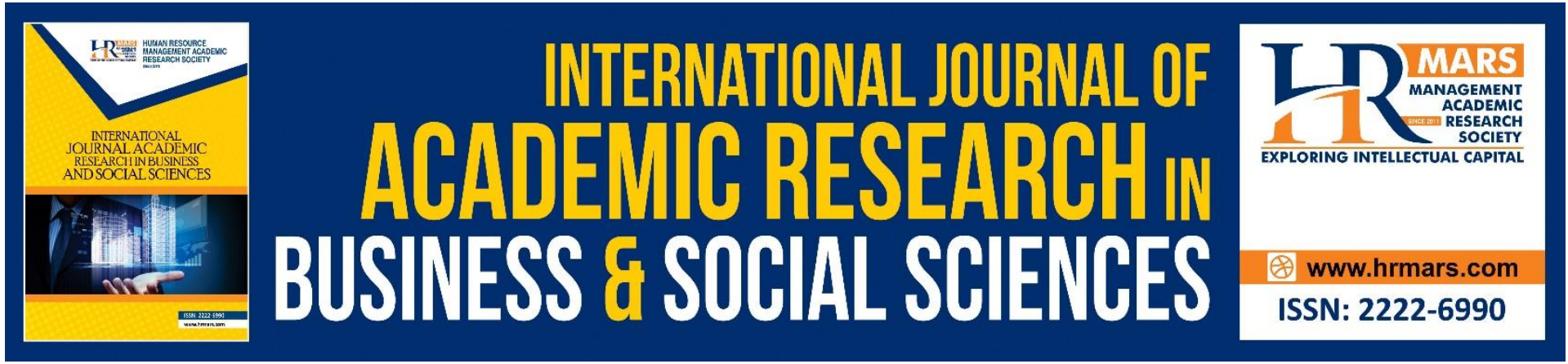

\title{
Effect of Electronic Banking on Customer Satisfaction in Kwara State, Nigeria
}

\author{
Abdulmalik Ajibola Raji, Abdolhossein Zameni, Muhammad Mansur \\ Abdulwakil
}

To Link this Article: http://dx.doi.org/10.6007/IJARBSS/v11-i7/10258

DOI:10.6007/IJARBSS/v11-i7/10258

Received: 24 May 2021, Revised: 27 June 2021, Accepted: 16 July 2021

Published Online: 23 July 2021

In-Text Citation: (Raji et al., 2021)

To Cite this Article: Raji, A. A., Zameni, A., \& Abdulwakil, M. M. (2021). Effect of Electronic Banking on Customer Satisfaction in Kwara State, Nigeria. International Journal of Academic Research in Business and Social Sciences, 11(7), 1571-1585.

Copyright: (c) 2021 The Author(s)

Published by Human Resource Management Academic Research Society (www.hrmars.com)

This article is published under the Creative Commons Attribution (CC BY 4.0) license. Anyone may reproduce, distribute, translate and create derivative works of this article (for both commercial and non-commercial purposes), subject to full attribution to the original publication and authors. The full terms of this license may be seen at: http://creativecommons.org/licences/by/4.0/legalcode

Vol. 11, No. 7, 2021, Pg. 1571 - 1585

http://hrmars.com/index.php/pages/detail/IJARBSS

JOURNAL HOMEPAGE

Full Terms \& Conditions of access and use can be found at

http://hrmars.com/index.php/pages/detail/publication-ethics 


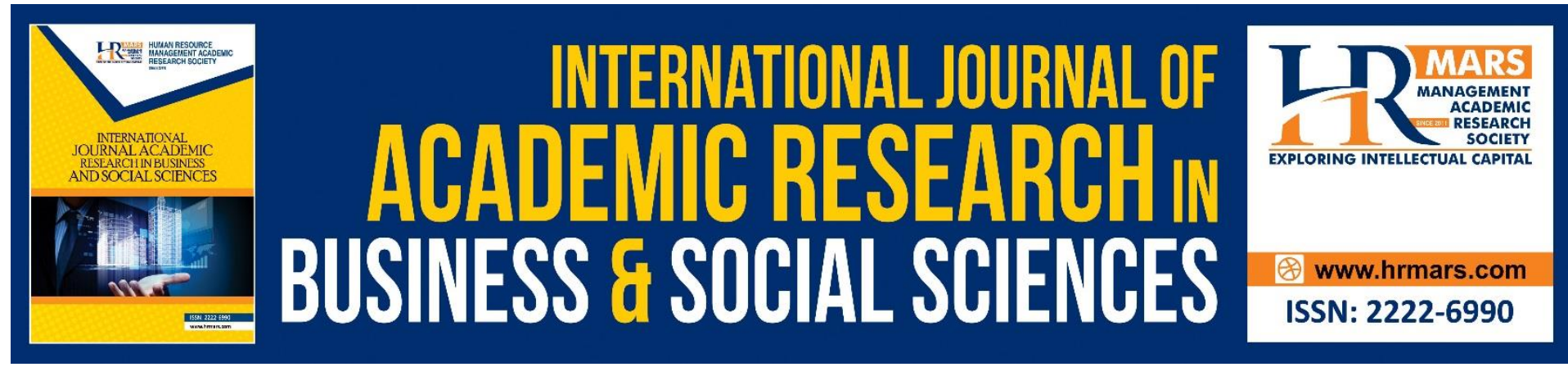

\title{
Effect of Electronic Banking on Customer Satisfaction in Kwara State, Nigeria
}

\author{
Abdulmalik Ajibola Rajia,b, Abdolhossein Zamenib, Muhammad \\ Mansur Abdulwakila \\ aSchool of Business and Economics, Universiti Putra Malaysia, ${ }^{b}$ Graduate School of \\ Bussiness, Segi University.
}

\begin{abstract}
This study investigated the effect of electronic banking on customer satisfaction in Nigeria's banking industry, specifically, in Kwara State. The study determined the attributes of ebanking services that are crucial to customers, and examined the impact of e-banking attributes on customers' satisfaction using correlation and regression analyses. In addition, the challenges associated with electronic banking use were highlighted. To this end, a total number of 390 respondents were included in the study through Google survey form (questionnaires). The study used security, reliability, ease to use and user-friendly, transactional speed, responsiveness as the independent variables while customer satisfaction as the dependent variable. The correlation result shows a positive correlation between all the independent variables and customer satisfaction. Similarly, the regression result shows that security, transactional speed, ease to use, reliability, and responsiveness have a positive and significant impact on customer satisfaction. Finally, the study recommends that bank managers should strengthen these attributes of e-banking and also look into the challenges highlighted by the respondent in order to maintain or improve customer satisfaction.
\end{abstract}

Keywords: E-banking, Customer Satisfaction, Kwara State Nigeria.

\section{Introduction}

In general, the impact of technology on banks is not limited to the financial services industry. Application of information and communication technology policies, processes, policies, and implementation methods in banking services has become a critical and timely issue for all banks, as well as a necessary prerequisite for global and regional banking competitiveness. The market climate in the financial sector is highly competitive as a result of this technological improvement, observing drastic changes and forcing banks to provide online assistance to their customers while using internet banking (Singh \& Kaur, 2013). According to Hammoud et al (2018), since the 16th century, businesses had to provide high standards for their goods and services. Any company needs to represent its clients as efficiently and as effectively as it wants. In recent years, banks have been struggling to offer the highest level of technical infrastructure, which has led to widespread use of e-banking platforms through the spread of websites to meet consumer needs. Despite the variations in prices and types of e-services 
offered, many banks use e-banking services to purchase, sell and exchange services via ecommerce websites.

The era of globalization is the 21st Century, transformed by the technological revolution. All facets of business are greatly affected by the Internet. Electronic business is no longer a choice for companies but a requirement (Bezhovski, 2016). According to various commercial activities, electronic banking has recently been introduced. Using internet platforms to improve the facilities, such as retail sales of goods and purchases of items. Regardless of the threats related to this current form of technology, the desire to make the planet a village has necessitated the development of a consumer economy. The adoption of electronic banking by commercial and financial institutions to more conveniently link banking operations or affairs than in previous years (Toor et al., 2016). As a result of technological advances, it is now easier for a controlling bank which is known as the parent bank to manage its distantly located subsidiary bank through electronic banking (Toor et al., 2016).

Raza et al (2020) defines online banking as a type of e-banking that allows customers to use multiple banking services, pay bills and make investments as an effective scheme of ecommerce and as a partner. Banks have introduced internet banking to enhance customer service and offer dual benefits at discounted prices these days. It's rare to come across a national bank that doesn't have any kind of electronic banking service, even in the most remote parts of the country. Online banking services are now being used as a strategic tool in developed and emerging areas of the world (Al-dmour, 2019). Competitiveness in the banking sector has called for an increase in industries around the world on board the electronic network. In order to minimize holding time, lapses, cost, and boost customer service support, banks decided to introduce, evaluate, examine and attempt to present internet banking services. Customers may use their internet banking services to access their bank account and may also make inquiries about their personal accounts, as well as make simple payments from their home computers and smartphones at work, whenever the timing of the transaction is convenient for them (Dauda \& Lee, 2016).

\section{Background of E-banking in Nigeria}

Electronic banking has become common in Nigerian banks and the financial services sector in general in recent years. Dauda \& Lee (2016) noted that when the CBN authorized "All states" Trust Bank's application to launch the ESCA closed device electronic purse, it was a significant step forward. The launch of such e-payment items in Nigeria began in 1996. Diamond Bank followed up with the introduction of a related product called 'Paycard' in February 1997. With the approval of Smart Card Nigeria Plc, a group of 19 banks formed a corporation named "valucard" in February 1998 to produce and administer cards that were issued by the member banks. E-money goods focused on cards presumed an inclusive forum. As a result, between 1998 and 2000, many banks unveiled their websites in order to provide Internet banking. The CBN granted Gem card Nigeria Limited, a group of over 20 banks, permission to introduce the 'Smartpay' scheme in November 1999.

Furthermore, the CBN approved a range of banks to provide international money transfer services, as well as mobile payments and online payments through the Internet, although on a narrow measure. Several other innovative electronic banking products were introduced to enhance service delivery and customer satisfaction. Consequently, the banking system now provides Automated Teller Machines (ATM), Cards and Mobile Banking. As a result, Nigerian banks are now aggressively engaged in the creation of new electronic delivery channels for banking goods and services in order to provide high quality service and greater customer 
satisfaction. While banks that do not offer such products are losing consumers at an increasing rate (Ekwueme \& Egbunike, 2012).

According to Ahmad (2016), for enhanced banking results, technology is the backbone and having advanced technology will have a huge benefit for all banking sectors. The banking situation today requires continuous creativity to encounter the desires and wishes of often difficult clients. Banks will have to integrate both newly created products and services with state-of-the-art technologies quickly and efficiently. As a result, many major banks have shifted their policies to focus on client retention and engagement by better service delivery, providing banks with a competitive advantage through minimizing operating costs and offering the highest possible customer satisfaction. Banks who do not provide internet banking have high potential to lose market share to their competitors. Hence, they give their clients internet banking to increase their satisfaction with banking customers.

According to Dauda \& Lee (2016), the history of self-service business in Nigeria is relatively recent, specifically, less than two decades ago. Banks have been Nigeria's leaders in this field, as a developing nation, and perhaps the country's largest self-service sector. Although the use of these services is on the increase, there is still a long way to go. Specifically, the adoption of recent technologies that allow for self-service like automated teller machines, mobile applications and so on are relatively inaccessible to a bulging population who are potential ebanking users, especially in developing/rural regions of Nigeria. Consequently, consumers in these regions are late adopters of the Internet and self-service platforms, including internet banking applications. Nonetheless, issues such as equipment failure, a lack of an appropriate alternative system to replace banking services whenever a technical situation occurs in the system, and technology, as well as consumer and service provider aversion to technical improvements as a result of danger, continue to exist, causing customers to be concerned, which in turn affects their level (s) of satisfaction.

Furthermore, numerous studies on the position of self-service platforms and customer satisfaction, including Nigeria, have been undertaken in both developed and developing countries. While research on e-banking and consumer satisfaction has been carried out in Nigeria, related studies have also been carried out in other countries. The majority of these studies are mainly focused on commercial cities such as Lagos-Nigeria, Osun - Nigeria, AccraGhana etc. Recently, several studies have been carried out on the quality of internet services in the context of online shopping, after-sales services and even in the banking sector, across different states, countries and regions of the world (see Ahmed et al., 2018; Al-dmour, 2019; Arcand et al., 2016; Dauda \& Lee, 2016; Pooya, 2020; Worku et al., 2016). However, there is little evidence that e-banking systems have effects on customer retention or satisfaction. To fill the void, this study aims to investigate the impact of e-banking on customer satisfaction in Kwara State, located in the North Central Zone of Nigeria.

\section{Review of Related Studies}

Many studies have been conducted to determine the impact of e-banking on consumer satisfaction. Any of these findings, such as those by (Ayo \& Oni, 2016; Dauda \& Lee, 2016), have conducted a mobile banking study in Nigeria for financial inclusion. In this study, feedback from the customers on the usage (e-banking benefits) and feedback from the customers on ease of use, security, reliability, speed and responsiveness is provided. The results indicate that the probability of usage influences the conduct of the customer's program, but customer feedback on the benefits pressured clients to the usage of Mobile Bank service area. This study did not take into account the total number of e-banking products 
that did not address the vulnerability of other alternate customers' e-banking services (ATMs, Internet-Banking).

According to Ahmed et al (2018), customer satisfaction and the standard of e-banking services are closely related. To evaluate this relationship, the study employed the Servqual measurement. They found that consumer trust is significantly influenced by metrics of reliability, tolerance, and durability. In addition, they revealed that reliability has a significant and positive effect on consumer satisfaction, and thus recommended that the banking industry should enhance indicators of customer satisfaction levels. Furthermore, the study highlighted the value of using Internet tools as a key tool for enhancing and developing customer satisfaction capabilities. The key issue is that most customers do not want to use internet banking services. Product quality in online banking is influenced by five variables: ease and speed, security and privacy, site design, material, and service levels, according to the researchers. Toor et al (2016)conducted an investigation into electronic banking and customer satisfaction in Pakistan. The study uses a sample of 250 respondents to gather the information. The SERVQUAL model was used by the researchers to determine the relationship between customer satisfaction and electronic banking. The findings indicate that there is a significant relationship between internet banking and customer satisfaction. The key aspects investigated are reliability, responsiveness, speed, and security. These variables appear to sufficiently result in consumer satisfaction. Hence, a review of these independent determinants of customer satisfaction is provided.

\section{Security}

The security of e-banking entails ensuring the records and information of customers are kept safe on the website (Hossain et al., 2014). Security can be ensured by providing information about the security of confidentiality and procurement mechanisms, as well as the display of reliable third-party logos. For instance, showing a trusted partner logo gives a certain level of safety and has an important effect on how consumers perceive the reliability of e-sellers (Hossain et al., 2014). A number of factors have been identified and investigated by researchers in terms of privacy and safety, including retaining confidentiality of transactions, preventing the exchange of individual data and ensuring a great level of safety for client data. According to Mei et al (2016), protection has had a huge effect on the satisfaction of clients. Another important factor that clients really worry about is privacy. Customers often think that when performing transactions through Internet banking, banks should secure their personal and financial details. According to Safi \& Awan (2018), Security plays an important role in Internet banking. With many cyber security protocols for encrypted data packets, customers are unaware of encryption. Due to limited security, some banks only use popular websites. Some versions of browsers are acceptable. Generally, these studies suggest that privacy would have a beneficial effect on the satisfaction of customers. Hence, we formulate our first hypothesis of the study as thus:

H1: There is a significant relationship between the security of customers' financial and personal information and customer satisfaction in Kwara State, Nigeria.

\section{Transactional Speed}

Transactional speed is another important determinant of customer satisfaction with ebanking. According to Mei et al (2016), Transactional speed is generally defined as the frequency of interruptions in the network link, the time it takes to access an Internet banking website and conduct any bank activities, the time spent on a page response by a customer, 
and the level of response of banks to a customer complaint. Internet banking has been plagued by a wide variety of graphics and an unreliable host server. Dauda \& Lee (2016), suggests that in developing societies, customers are more sensitive to the speed at which their transaction is completed. Empirical evidence indicates that when this transaction time is shortened, individuals choose to serve themselves and saving time is an important concept for those who use internet banking (Ahmed et al., 2018; Toor et al., 2016). In light of this, we propose the following second hypothesis for the study:

H2: There is a significant relationship between transactional speed and customer satisfaction in Kwara State, Nigeria.

\section{Ease to Use and User Friendliness}

Ease to use and/or user friendliness is considered an important concept in e-banking as it significantly affects the satisfaction of customers. According to Jaspal \& Parminderjit (2013)ease to use is measured as the degree to which an individual feels it is easy to use a specific service. Pooya (2020) suggested that one of the most significant factors to be considered is the ease of use of internet banking websites and Apps. Furthermore, the study indicates that one of the most important characteristics of a customer's acceptance is the ease of use of an innovative. It also indicates that customers choose different service options based on the effort expended to use the service. While Kundu (2015) suggests that attributes of ease of use and user friendliness are considered to be acceptable and are included in the initiative and difficulty attributes. In addition, Mei et al. (2016) looked into the factors that influence people over the use of internet banking in Malaysia. The study found that ease of use and user friendliness are essential considerations in deciding whether or not internet banking is embraced, used and leads to satisfaction of customers.

H3: There is a significant relationship between User-Friendliness and consumer satisfaction in Kwara State, Nigeria.

\section{Reliability}

Reliability is defined in terms of the quality of the website's operation, applies in particular to the technical functions of the website, its availability and its proper functionality (Khatoon et al., 2020). While Ayo \& Oni (2016), define reliability as the fulfillment of duties in areas such as accuracy of calculations, proper registration and delivery of service within a satisfactory time frame. In this study, the level of effectiveness of which e-banking solutions complete transactions is referred to as efficiency. It is expected that the ability of the e-banking system to complete the transaction effectively would lead to consumers appreciating the system's quality. Many experiments have discovered that reliability plays an important role in deciding service efficiency (Ahmed et al., 2018; May et al., 2017; Mei et al., 2016). In addition, Mei et al. (2016) suggests that the level of customer satisfaction is significantly influenced by the efficiency of e-banking services in terms of reliability.

H4: There is a significant relation between the reliability of e-banking and customer satisfaction in Kwara State, Nigeria.

\section{Responsiveness}

According to Toor et al. (2016), responsiveness is the desire to serve the clients of the bank and provide them with quick provision. This type of operation can take four different forms: first, the electronic banking system can effectively manage and operate the service; Secondly, e-banking networks can guide consumers on how to react appropriately in the event of a loss; 
thirdly, it includes quick fixes for errors that may occur in e-banking operations; fourthly, it can help customers resolve issues with on-the-spot answers. Hammoud et al (2018) suggests that individuals' general expectations of service quality are adversely affected by sluggish service. In addition, Mei et al (2016) indicates that e-banking has a greater level of responsiveness, allowing consumers to access their accounts at any time and from anywhere. As a result, the study concluded that responsiveness has a strong link with customer satisfaction. Based on these empirical studies, we develop the fifth hypothesis as thus:

H5: There is a significant relationship between the responsiveness of e-banking gadgets and customer satisfaction in Kwara State, Nigeria.

\section{Methodology}

The population in this study focuses on active users of e-banking in Kwara State, Nigeria. To gain access to the bank's clients, a convenient sample selection was used. Additionally, the use of online questionnaires (google survey) is due to the COVID-19 which necessitates maintaining social distancing. The questionnaires were administered online to a sample of ebanking users. For the purpose of this study, a total of three hundred and ninety (390) samples of bank customers were used. The decision to use a total sample size of 390 is supported by the Krejcie \& Morgan (1970) sample size determination technique (table), which suggests that a suitable minimum sample size of 384 respondents is appropriate for an undefined population or a total population of up to a million and above. The overall hypothesis of this study suggests a positive significant relationship between e-Banking and consumer satisfaction. It was, however, broken down into the five testable hypotheses which were introduced in section 2, i.e. ( $\mathrm{H} 1, \mathrm{H} 2, \mathrm{H} 3, \mathrm{H} 4$, and $\mathrm{H} 5)$.

\section{Method of Estimation}

The data was analyzed using the statistical package for social science (SPSS) and STATA. The data was evaluated using Pearson Correlation, and multiple regression analysis was used to examine the impact of e-banking on customer satisfaction, while descriptive statistics were used to analyze the demographic information. In addition, a multivariate or multiple linear regression model is employed to test the impact of e-banking services on customer satisfaction in the Nigerian banking sector. The advantage of this empirical approach is that it makes it possible to estimate the impact of each independent variable (attributes of ebanking) on the dependent variable (customer satisfaction). The model is therefore specified as follow:

$Y=\alpha+\gamma 1 X 1+\gamma 2 X 2+\gamma 3 X 3+\cdots,+\gamma n X n+\varepsilon$

Where: $Y$ represents the dependent variable (satisfaction of customers), X1, X2, X3, .., Xn represent sets of independent variables, $Y$ denotes the estimated coefficient of the independent variables and $\varepsilon$ is error term. The model can further be augmented to accommodate the specific individual independent variables. Thus, the model; is rewritten as follows:

$Y=\alpha+\gamma 1 S E C+\gamma 2 S P E E D+\gamma 3 R E L+\gamma 4 \mathrm{RES}+\gamma 5 \mathrm{EASE}+\varepsilon$

Where: SEC: represents security, SPEED denotes transactional speed, REL represents reliability, RES denotes responsiveness, easy access of e-banking is represented by EASE, while $\varepsilon \quad$ is as defined in equation (1). 


\section{Results and Discussions}

The aim of this study is to investigate the effects of e-banking on customer satisfaction in Kwara State, Nigeria. For this study, a total of 390 people were polled, and the descriptive statistics of frequency and percentages were used for the analysis of demographic data (see appendix 1). The respondents to the survey were bank clients across different banks in Nigeria, specifically, Kwara State. Out of the 390 respondents, $36.2 \%$ are between the ages of 18-25 years, $22.3 \%$ are between the ages of $26-30$ years, $23.6 \%$ are between the ages of 31 40 years and $17.9 \%$ are above the age of 40 . These findings indicate that people over the age of 40 are older members of the older generation, which may explain why they do not use ebanking services. The largest age group was 18 to 25 years, however. In fact, these results imply that the highest age range is 18 to 30 years, the age of the majority of university students. These results are backed by a study by (Bezhovski, 2016). The majority of the respondents had higher education, with $47.7 \%$ having at least a bachelor's degree, while 21.3 percent had a master's degree and $8.5 \%$ had a doctorate degree. Most of the respondents (60.3\%) earned an annual income that ranged between US $\$ 4,700$ and US $\$ 6,000$, while $28.7 \%$ earned between US $\$ 6,000$ and US $\$ 14,200$, about $8 \%$ earned between US $\$ 14,200$ and US $\$ 31,000$ while, only a few (3.1\%) earned above US $\$ 31,000$ which indicates that most of the respondents belonged to the low income category.

The Kaiser-Meyer-Olkin and Bartlett's test of sphericity test was used to measure Sampling Adequacy and Cronbach's alpha was used to test the reliability. The Kaiser-Meyer-Olkin sampling adequacy is known to be adequate when the KMO statistic is close to 1.0, which implies that the sampling is adequate while a value below 0.5 implies that the sample is not sufficient. While, the Bartlett's test of sphericity will test the correlation matrix of the hypothesis which is an identity matrix. It suggests that the variables may be unrelated, which will lead to structure detection because the variables are thought to be unsuitable. A significant level of less than 0.05 implies that factor analysis is useful. According to Nunnally $\&$ Bernstein (1995), Cronbach alpha has a range of scores from 0 to 1 . Cronbach alpha scores above 0.7 suggest that a one-dimensional product has high internal reliability (Nunnally \& Bernstein, 1995). As shown in Table 1, the tests show that the sample is adequate for the current study.

Table 1: Test of adequacy

\begin{tabular}{l}
\hline \multicolumn{1}{c}{ KMO and Bartlett's test } \\
\hline $\begin{array}{l}\text { Kaiser-Meyer-Olkin Measure } \\
\text { of Sampling Adequacy. } \\
\text { Bartlett's Test of Sphericity } \\
\text { (Sig.) }\end{array}$ 0.915 \\
\hline On the other hand, Cronbach's alpha applied to test the reliability of all variables. The \\
Cronbach alpha has a range of scores from 0 to 1. The variable is considered reliable given a \\
Cronbach's alpha value greater than 0.70 (Nunnally \& Bernstein, 1995). Therefore, all \\
variables in this study are acceptable as shown in Table 2. Cronbach alpha scores above 0.7 \\
suggest that a one-dimensional product has high internal reliability.
\end{tabular}


Table 2: Results of Reliability Test for the Instruments

\begin{tabular}{lcc}
\hline Variables & Number of Items & Cronbach's alpha \\
\hline Customer satisfaction & 4 & 0.837 \\
Security & 4 & 0.826 \\
Transactional speed & 4 & 0.763 \\
User friendliness & 4 & 0.827 \\
Reliability & 4 & 0.708 \\
Responsiveness & 4 & 0.727 \\
\hline
\end{tabular}

To test the hull hypothesis of "no significant correlation between e-banking attributes and customer satisfaction," data on e-banking attributes and customer satisfaction on a five-point response scale were sorted and analyzed. The result, as presented in Table 3, indicated that there is a significant positive correlation $(r=0.634$; with a $p$-value $=0.000)$ between e-banking security and customer satisfaction, implying that security plays a significant role in customer satisfaction. Similarly, results also indicate that there is a positive and significant correlation $(r=0.726$ with a $p$-value $=0.000)$ between transactional speed and customer satisfaction. This implies that the customer attaches significant importance to transactional speed considering the role it plays in customer satisfaction. In addition, ease to use shows a positive significant correlation with customer satisfaction given $r=0.681$ with a $p$-value of 0.000 . This finding implies that customers' satisfaction is highly correlated with user friendliness of e-banking. Also, reliability is positively correlated with customer satisfaction given $r=0.791$ with a $p$-value of 0.000 . This finding implies that reliability holds a very strong position when determining customer satisfaction. Lastly, responsiveness is positively correlated with customer satisfaction given $r=0.696$ with a $p$-value of 0.000 . This finding implies that customers' satisfaction can highly be determined by responsiveness. Therefore, on a general note, the null hypothesis stating that there is no significant relationship between the attributes of ebanking and customers' satisfaction is rejected.

Table 3: Pearson's correlation analysis between Attributes of e-banking and Customer Satisfaction $(n=390)$

\begin{tabular}{lccc}
\hline Variables & Observations & Correlation & P-value \\
\hline Satisfaction $(\mathrm{Y})$ & - & - & - \\
Security & 390 & $0.634^{* *}$ & 0.000 \\
Transactional Speed & 390 & $0.726^{* *}$ & 0.000 \\
Ease to Use & 390 & $0.681^{* *}$ & 0.000 \\
Reliability & 390 & $0.791^{* *}$ & 0.000 \\
Responsiveness & 390 & $0.696^{* *}$ & 0.000 \\
\hline
\end{tabular}

Note: ${ }^{* *}$. Correlation is significant at the 0.01 level.

In addition, this study further examined the impact of e-banking attributes on customers' satisfaction. To this end, Table 4 presents the results. To begin with, the R-squared $(0.744)$ and adjusted $R$ (0.7441) of the estimated model suggests that 74 percent of the variance in the dependent variable (customer satisfaction) is accounted for by the independent variables (security, reliability, ease to use and user-friendly, transactional speed, responsiveness). This indicates that there is a significant relationship between e-banking and customer satisfaction. 
As a result, it can be inferred that the e-banking attribute and customer satisfaction have a linear relationship. On the other hand, to ascertain that our model is free from the problem of multi-collinearity, the variance inflation factor (VIF) test was conducted. The result shows that all VIF values are sufficiently below the common threshold value of VIF $=10.00$, with an average VIF value of 2.89 . Thus, there is no multi-collinearity problem between the independent variables.

In Table 4, results show that security, speed, ease of use, reliability, and responsiveness have positive significant impacts on customer satisfaction. Specifically, speed, reliability, and responsiveness are significant at $1 \%$ level, while the coefficients of security and ease to use, are significant at $5 \%$ level.

Table 4: Summary Results on the Impact of e-banking Attributes on Customer Satisfaction

\begin{tabular}{lccccc}
\hline Variables & $\begin{array}{c}\text { BETA } \\
\text { Coefficients }\end{array}$ & $\begin{array}{c}\text { Standard } \\
\text { Errors }\end{array}$ & T-statistics & P-values & VIF \\
\hline Security & $0.078^{* *}$ & 0.035 & 2.27 & 0.024 & 2.21 \\
Speed & $0.161^{* * *}$ & 0.043 & 3.76 & 0.000 & 3.31 \\
Ease to Use & $0.084^{* *}$ & 0.041 & 2.04 & 0.042 & 2.99 \\
Reliability & $0.330^{* * *}$ & 0.046 & 7.09 & 0.000 & 3.84 \\
Responsiveness & $0.241^{* * *}$ & 0.034 & 7.10 & 0.000 & 2.12 \\
Constant & $0.311^{* * *}$ & 0.075 & 4.13 & 0.000 & - \\
\hline R Square & 0.744 & - & - & - & - \\
Adjusted R & 0.741 & - & - & - & - \\
\hline
\end{tabular}

Note: ${ }^{* *}$ and ${ }^{* * *}$, denote significance at the 0.05 and 0.01 level, respectively.

Furthermore, the results imply that a 10 percentage increase in security will lead to an increase in customer satisfaction by 0.78 and also a 10 percentage increase in transactional speed will lead to an increase in customer satisfaction by $1.6 \%$. In addition, a rise in user friendliness by $10 \%$ will increase customer satisfaction by 0.8 , while a $10 \%$ increase in reliability will increase customer satisfaction by $3.3 \%$. Finally, a $10 \%$ increase in responsiveness will result in an increase in customer satisfaction by $2.4 \%$. In summary, the results show that reliability has the highest impact on customer satisfaction compared to other attributes of e-banking that are included in this study.

\section{Challenges Associated with the Use of e-banking Services}

This segment summarizes the challenges bank customers face while using e-banking. According to the respondents, 173 respondents (44.4\%) of the total respondents claim that they do not face any challenge (s) while using e-banking and believe that it is very effective and they are happy with all the services provided by their various banks. On the other hand, 217 respondents $(55.6 \%)$ of the total respondents claim that they face several challenges while using e-banking.

Accessibility is one of the most frequently mentioned challenges of e-banking in Kwara state. This was expressed in the form of the lack of access to the services except through the mobile applications which are majorly limited to well trained and fortunate members of the communities. Similarly, application update related problems, limited ATM points, inconsistent and exorbitant bank charges, and lack of prompt response to customers' complaints are some of the challenges that are more prevalent with most banks. The lack of adequate security to protect the account information of customers and poor bank network 
service are also perceived as some of the challenges of e-banking in the region. More specifically, the bank network is highlighted as a major challenge by respondents. This problem prevents the customer from transferring to other customers. Payment via e-baking or other e-banking features may be difficult when there are network issues. This issue is also common with the use of ATMs, where accounts are debited while the machines fail to dispense cash.

Another major problem highlighted by the customers is the proliferation of transactions. This is a transaction error that usually occurs when there is a serious network issue or a problem that could be caused when there is a recent upgrade of mobile applications. The respondents also note that the ability to incorporate modified software or applications after the previous version is obsolete without bugs or errors is a serious challenge, while some argue that after the software update the e-bank applications do not function properly. In the case of proliferation of transactions, a refund is expected for every double transaction. However, this process could be tedious as a result of poor customer care response to issues, which is another major challenge.

\section{Conclusion}

This study investigated the effects of electronic banking on consumer satisfaction in Kwara state, Nigeria. This study has shown that the majority of customers attribute their satisfaction to reliability, which is consistent with the findings that the efficiency of e-banking has a major effect on customer satisfaction among e-banking users in Kwara State, Nigeria. This is a source of concern and a line of action for the banks to continue to innovate as well as improve the reliability of their e-banking services. Generally, this study concludes that all the attributes of e-banking included in this study (security, transactional speed, responsiveness, user friendliness and reliability) have a strong relationship with customer satisfaction, which indicates that the relationship of the dependent variable and the independent variables are sufficient to explain the emergence, importance, persistence, as well as success of the region's e-banking services.

This conclusion have several theoretical underpinnings and background. The study lend empirical support to the technology acceptance model (TAM) which points out that the utility perceived and perceived ease of use of an innovation may influence the attitudes of individuals in favor of their intention to use an invention to mediate the actual use of the method. Hence, this principle suggests that perceived importance and ease of use are critical factors in the acceptance and use of a device or service. Given that e-banking provide consumers with convenient, fast and cost effective service, while the banks are keen to expand their market share with e-banking services, This study also conclude that mobile technology growth present financial services suppliers with the opportunity to implement new acceptable financial technologies.

This study, however, recommends that the bank should make an effort to correct some of the limitations associated with their services in order to maintain a healthy relationship with their customers. For example, the issue of proliferation of transactions or double transactions should be strictly looked into as various customers have bitter experiences with this issue. However, should this issue occur, the banks should set a means to reduce the period of processing refund to the minimum to prevent customer dissatisfaction with the bank. In addition, banks should consider improving or maintaining a standard operational network in order to prevent the problem of transaction error that occurs when there is a serious network issue or a problem that could be caused when there is a recent upgrade of mobile 
applications. Similarly, the bank should make their website simple (user-friendly) and secure. This would increase customers' confidence in the use of e-banking.

In addition, a replica of this study can be carried out by means of comparing the e-banking services of local banks and international banks and the levels of satisfaction derived by their respective customers, in order to have a clear picture of the basis for comparison between the banks. This recommendation is basically in line with expectation confirmation theory of satisfaction. The theory suggests that the result of direct experience with a product or service is achieved by comparing the expected quality and satisfaction of different products.

\section{References}

Ahmad, N. M. (2016). Risk of money laundering in the US: HSBC case study. Journal of Money Laundering Control, 19(3), 225-237. https://doi.org/10.1108/JMLC-01-20150003

Ahmed, A., Hamid, M., Mohamed, N., Alabsy, A., \& Mukhtar, M. A. (2018). The Impact of Electronic Banking Services on Customer Satisfaction in the Sudanese Banking Sector. 11(6), 102-109. https://doi.org/10.5539/ibr.v11n6p102

Al-dmour, H. H. (2019). Investigating the impact of ECRM success factors on business performance Jordanian commercial banks. 31(1), 105-127. https://doi.org/10.1108/APJML-10-2017-0270

Arcand, M., Promtep, S., \& Brun, I. (2016). Mobile banking service quality and customer relationships. https://doi.org/10.1108/IJBM-10-2015-0150

Ayo, C. K., \& Oni, A. A. (2016). E-banking users ' behaviour : e-service quality, attitude, and customer satisfaction. 34(3), 347-367. https://doi.org/10.1108/IJBM-12-2014-0175

Bezhovski, Z. (2016). The Benefits of the Electronic Customer Relationship Management to the Banks and their Customers. 7(4), 112-116.

Dauda, S. Y., \& Lee, J. (2016). Quality of service and customer satisfaction : a conjoint analysis for the Nigerian bank customers. 34(6), 841-867. https://doi.org/10.1108/IJBM-04-2015-0062

Ekwueme, M. C., \& Egbunike, A. (2012). AN EMPIRICAL ASSESSMENT OF THE OPERATIONAL EFFICIENCY OF ELECTRONIC BANKING : EVIDENCE OF AN EMPIRICAL ASSESSMENT OF THE OPERATIONAL EFFICIENCY OF ELECTRONIC BANKING : EVIDNCE OF NIGERIAN BANKS. November.

Hammoud, J., Bizri, R. M., \& Baba, I. El. (2018). The Impact of E-Banking Service Quality on Customer Satisfaction : Evidence From the Lebanese Banking Sector. https://doi.org/10.1177/2158244018790633

Hossain, M. A., Dwivedi, Y. K., \& Binte, S. (2014). Total Quality Management \& Business Excellence Developing and validating a hierarchical model of service quality of retail banks. December, 37-41. https://doi.org/10.1080/14783363.2013.856545

Jaspal, S., \& Parminderjit, K. (2013). Customers' attitude towards technology based services provided by select Indian banks: Empirical analysis. International Journal of Commerce and Management, 23(1), 56-68. https://doi.org/10.1108/10569211311301439

Khatoon, S., Zhengliang, X., \& Hussain, H. (2020). The Mediating Effect of Customer Satisfaction on the Relationship Between Electronic Banking Service Quality and Customer Purchase Intention : Evidence From the Qatar Banking Sector. 2699. https://doi.org/10.1177/2158244020935887

Krejcie, R. V, \& Morgan, D. (1970). ACTIVITIES. 607-610.

Kundu, S. (2015). Impact of trust on the relationship of e-service quality and customer 
satisfaction. 10(1), 21-46. https://doi.org/10.1108/EMJB-10-2013-0053

May, W., Stella, C., \& Trey, D. (2017). The impact of personalization and compatibility with past experience on e-banking usage. International Journal of Bank Marketing, 35(1), 45-55. https://doi.org/10.1108/IJBM-04-2015-0046

Mei, G., Sook, Y., Kah, L., \& Seng, T. (2016). Understanding Customer Satisfaction of Internet Banking : A Case Study In Malacca. Procedia Economics and Finance, 37(16), 80-85. https://doi.org/10.1016/S2212-5671(16)30096-X

Nunnally, J., \& Bernstein, I. (1995). Psychometric Theory (3rd ed .). 19(3), 303-305.

Pooya, A. (2020). Investigating the e ff ect of perceived quality of self-service banking on customer satisfaction. 13(2), 263-280. https://doi.org/10.1108/IMEFM-12-2018-0440

Raza, S. A., Umer, A., Qureshi, M. A., \& Dahri, A. S. (2020). Internet banking service quality, e-customer satisfaction and loyalty : the modified e-SERVQUAL model. 32(6), 14431466. https://doi.org/10.1108/TQM-02-2020-0019

Safi, K. U., \& Awan, T. M. (2018). IMPACT OF PERCEIVED SERVICE QUALITY ON CUSTOMER LOYALTY : EVIDENCE FROM CASUAL DINING RESTAURANTS OF. 08(01), 30-46.

Singh, J., \& Kaur, P. (2013). Customers ' attitude towards technology based services provided by select Indian banks. https://doi.org/10.1108/10569211311301439

Toor, A., Hunain, M., Hussain, T., Ali, S., \& Shahid, A. (2016). The Impact of E-Banking on Customer Satisfaction : Evidence from Banking Sector of Pakistan. 5(2), 27-40. https://doi.org/10.5430/jbar.v5n2p27

Worku, G., Tilahun, A., \& Ma, T. (2016). The Impact of Electronic Banking on Customers ' Satisfaction in Ethiopian Banking Industry (The Case of Customers of Dashen and Wogagen Banks in Gondar City ) Business \& Financial Affairs. 5(2).

https://doi.org/10.4172/2167-0234.1000174 
INTERNATIONAL JOURNAL OF ACADEMIC RESEARCH IN BUSINESS AND SOCIAL SCIENCES Vol. 11, No. 7, 2021, E-ISSN: 2222-6990 @ 2021 HRMARS

\section{Appendix}

Socio-demographic characteristics of the respondents

\begin{tabular}{|c|c|c|}
\hline Variable & Frequency & Percentage \% \\
\hline \multicolumn{3}{|l|}{ GENDER } \\
\hline Male & 218 & 55.9 \\
\hline Female & 172 & 44.1 \\
\hline Total & 390 & 100.0 \\
\hline \multicolumn{3}{|l|}{ AGE } \\
\hline $18-25$ years & 141 & 36.2 \\
\hline $26-30$ years & 87 & 22.3 \\
\hline $31-40$ years & 92 & 23.6 \\
\hline Above 40 years & 70 & 17.9 \\
\hline Total & 390 & 100.0 \\
\hline \multicolumn{3}{|l|}{ EDUCATION LEVEL } \\
\hline Primary & 9 & 2.3 \\
\hline Secondary & 11 & 3.6 \\
\hline Diploma & 65 & 16.7 \\
\hline Bachelor Degree & 186 & 47.7 \\
\hline Master's Degree & 83 & 21.3 \\
\hline Doctorate Degree & 33 & 8.5 \\
\hline Total & 390 & 100.0 \\
\hline \multicolumn{3}{|l|}{ MARITAL STATUS } \\
\hline Single & 217 & 55.6 \\
\hline Married & 156 & 40 \\
\hline Widow & 8 & 2.1 \\
\hline Divorced & 9 & 2.3 \\
\hline
\end{tabular}


INTERNATIONAL JOURNAL OF ACADEMIC RESEARCH IN BUSINESS AND SOCIAL SCIENCES Vol. 11, No. 7, 2021, E-ISSN: 2222-6990 @ 2021 HRMARS

Total

390 100.0

Source: Field Survey (2021)

Income Level of Respondents

\begin{tabular}{lcc}
\hline Variable & Frequency & Percentage \% \\
\hline MONTHLY INCOME (\#) & 235 & 60.3 \\
US\$4,700 - US\$6,000 & 112 & 28.7 \\
US\$6,000 - US\$14,200 & 31 & 7.9 \\
US\$14,200 - US\$31,000 & 12 & 3.1 \\
Above US\$31,000 & 390 & 100.0 \\
Total & & \\
\hline
\end{tabular}

